\title{
Trends in Preventative Health Services for Veterans with Military Coverage Compared to Non-Military Coverage
}

\author{
Sri Lekha Tummalapalli, MD, MBA ${ }^{1,2}$ (1) and Salomeh Keyhani, $M D, M^{2} H^{2,3}$
}

'Division of Nephrology, University of California, San Francisco, CA, USA; ${ }^{2}$ Department of Medicine, University of California, San Francisco, CA, USA; ${ }^{3}$ San Francisco Veterans Affairs Health Care System, San Francisco, CA, USA.

J Gen Intern Med 35(4):1330-3

DOI: $10.1007 / \mathrm{s} 11606-019-05377-\mathrm{w}$

(c) Society of General Internal Medicine 2019

\section{INTRODUCTION}

Veterans have a wide range of health care coverage options through military sources, including Veterans Affairs health care and TRICARE health plans, and non-military sources, including private insurance, Medicare, and Medicaid. ${ }^{1}$ Multiple comparisons have demonstrated that care in VA facilities outperforms care in health care settings; however, differences in care delivery based on coverage source have not been fully evaluated. $^{2-4}$ Increasingly, non-military payors have established numerous quality reporting programs and incentives in primary care, which may impact care delivery differentially in veterans with military compared with non-military coverage. ${ }^{5}$ We examined the quality of preventative care delivery over time among veterans with military coverage compared with non-military coverage.

\section{METHODS}

We performed a serial cross-sectional analysis of the Behavioral Risk Factor Surveillance System survey, a federally funded nationally representative telephone survey. Our sample included veterans, and our predictor was TRICARE, VA, or military care, assessed by "What is the primary source of your health care coverage?" We assessed two time periods, 2000 and 2014-2017, as coverage information for Veterans was available for those years in the BRFSS.

Our primary outcomes were preventative health services, according to United States Preventative Services Task Force recommendations, the Centers for Disease Control, and American Diabetes Association guidelines. Outcomes were categorized as cancer screening (colorectal cancer, breast cancer, cervical cancer); cardiovascular risk reduction (cholesterol checked in the low-risk and high-risk individuals, aspirin use); infectious disease prevention (influenza vaccination,

Received June 19, 2019

Revised July 15, 2019

Accepted September 12, 2019

Published online October 16, 2019 pneumonia vaccination, HIV testing); and diabetes care (hemoglobin A1c checked, foot examination, eye examination, and influenza vaccination, pneumonia vaccination).

We first compared the receipt of preventative health care in veterans with military coverage compared with non-military coverage using chi-squared tests, stratified by time period. We performed multivariable logistic regression to assess the difference in military compared with non-military coverage, adjusting for patient demographics (age, sex, and race) and social factors (employment, education, income, and marital status). We assessed the interaction of military coverage across the two time periods to determine if differences between military and non-military coverage were changing over time.

\section{RESULTS}

Survey responses from 67,833 Veterans were included in the analysis, representing 36,029,691 observations from US adults. Participants with primary military coverage $(N=$ $11,088)$ were less likely to be non-Hispanic white $(69 \%$ vs. $81 \%, p<0.001)$, were employed for wages $(52 \%$ vs. $56 \%$, $p<0.001$ ), have completed $\geq 4$ years of college ( $25 \%$ vs. $29 \%$, $p<0.001$ ), and have an income of $\$ 50,000$ or more (36\% vs. $52 \%, p<0.001)$, compared with those with non-military coverage $(N=56,745)$.

In 2000, veterans with military coverage had a higher prevalence of cervical cancer screening (98\% vs. $90 \%$, $p<0.001$ ), cholesterol checked in low-risk individuals $(93 \%$ vs. $83 \%, p=0.032)$, influenza vaccination $(53 \%$ vs. $36 \%$, $p<0.001$ ), and HIV testing ( $89 \%$ vs. $59 \%, p<0.001$ ) compared with those with non-military coverage in unadjusted analyses. In 2014-2017, prevalence of colorectal screening $(85 \%$ vs. $79 \%, p<0.001)$, breast cancer screening ( $89 \%$ vs. $78 \%, p<0.001)$, influenza vaccination $(59 \%$ vs. $53 \%, p<$ 0.001 ), and HIV testing ( $78 \%$ vs. $56 \%, p<0.001$ ) was higher in those with military coverage compared with non-military coverage (Table 1). When adjusted for patient demographics and social factors, in 2014-2017, military coverage was associated with higher colorectal cancer screening, breast cancer screening, influenza vaccination, and HIV testing compared with non-military coverage (Table 1). 
Table 1 Use of Recommended Preventative Health Services in Veterans with Primarily Military Coverage Compared with Non-Military Coverage, 2000 and 2014-2017

\begin{tabular}{|c|c|c|c|c|c|c|c|c|c|c|}
\hline $\begin{array}{l}\text { Preventative } \\
\text { health service }\end{array}$ & $\begin{array}{l}2000 \\
(N)\end{array}$ & $\begin{array}{l}\text { Military } \\
\text { coverage, } \\
2000 \\
(\%, \\
n=1923)\end{array}$ & $\begin{array}{l}\text { Non- } \\
\text { military } \\
\text { coverage, } \\
2000 \\
(\%, \\
n=13,260)\end{array}$ & $\begin{array}{l}p \\
\text { value, } \\
\text { unadj. }\end{array}$ & $\begin{array}{l}\text { Adjusted } \\
\text { OR } \\
\text { (95\% CI) } \\
\text { Military } \\
\text { coverage, } \\
2000 \\
\text { (ref. } \\
\text { non-VA } \\
\text { coverage) }\end{array}$ & $\begin{array}{l}2014- \\
2017 \\
(N)\end{array}$ & $\begin{array}{l}\text { Military } \\
\text { coverage, } \\
\text { 2014-2017 } \\
(\%, \\
n=9165)\end{array}$ & $\begin{array}{l}\text { Non- } \\
\text { military } \\
\text { coverage, } \\
2014-2017 \\
(\%, \\
n=43,485)\end{array}$ & $\begin{array}{l}p \\
\text { value, } \\
\text { unadj. }\end{array}$ & $\begin{array}{l}\text { Adjusted } \\
\text { OR } \\
\text { (95\% CI) } \\
\text { Military } \\
\text { coverage, } \\
\text { 2014-2017 } \\
\text { (ref. } \\
\text { non-VA } \\
\text { coverage) }\end{array}$ \\
\hline \multicolumn{11}{|c|}{ Cancer screening } \\
\hline $\begin{array}{l}\text { Colorectal } \\
\text { cancer } \\
\text { screening }^{\text {a }}\end{array}$ & - & - & - & - & - & 25,218 & 84.6 & 79.2 & $\begin{array}{l}< \\
0.001\end{array}$ & $\begin{array}{l}1.82 \\
(1.53 \text { to } \\
2.18)\end{array}$ \\
\hline $\begin{array}{l}\text { Breast cancer } \\
\text { screening }^{\mathrm{b}}\end{array}$ & 239 & 84.5 & 83.7 & 0.94 & $\begin{array}{l}0.81 \\
(0.17 \text { to } \\
3.94)\end{array}$ & 2116 & 88.8 & 78.1 & $\begin{array}{l}< \\
0.001\end{array}$ & $\begin{array}{l}2.37 \\
(1.52 \text { to } \\
3.70)\end{array}$ \\
\hline $\begin{array}{l}\text { Cervical } \\
\text { cancer } \\
\text { screening }^{\mathrm{c}}\end{array}$ & 1,533 & 97.6 & 90.1 & $\begin{array}{l}< \\
0.001\end{array}$ & $\begin{array}{l}3.17 \\
(1.48 \text { to } \\
6.81)\end{array}$ & 2851 & 82.7 & 82.5 & 0.96 & $\begin{array}{l}0.88 \\
(0.58 \text { to } \\
1.31)\end{array}$ \\
\hline \multicolumn{11}{|c|}{ Cardiovascular risk reduction } \\
\hline $\begin{array}{l}\text { Cholesterol } \\
\text { checked in } \\
\text { low-risk } \\
\text { individuals }\end{array}$ & 960 & 92.5 & 83.1 & 0.03 & $\begin{array}{l}2.78 \\
(1.02 \text { to } \\
7.59)\end{array}$ & 4855 & 96.2 & 96.1 & 0.94 & $\begin{array}{l}1.14 \\
(0.35 \text { to } \\
3.67)\end{array}$ \\
\hline $\begin{array}{l}\text { Cholesterol } \\
\text { checked in } \\
\text { high-risk } \\
\text { individuals }\end{array}$ & 488 & 95.5 & 93.8 & 0.61 & $\begin{array}{l}2.14 \\
(0.51 \text { to } \\
8.94)\end{array}$ & 3566 & 97.5 & 97.9 & 0.77 & $\begin{array}{l}0.66 \\
(0.11 \text { to } \\
3.97)\end{array}$ \\
\hline Aspirin use $\mathrm{e}^{\mathrm{e}}$ & 1,871 & 31.9 & 40.2 & 0.12 & $\begin{array}{l}0.72 \\
(0.44 \text { to } \\
1.18)\end{array}$ & 192 & 40.6 & 44.7 & 0.71 & $\begin{array}{l}1.11 \\
(0.36 \text { to } \\
3.42)\end{array}$ \\
\hline \multicolumn{11}{|c|}{ Infectious disease prevention } \\
\hline $\begin{array}{l}\text { Influenza } \\
\text { vaccination }\end{array}$ & 4,588 & 53.4 & 36.4 & $\begin{array}{l}< \\
0.001\end{array}$ & $\begin{array}{l}1.88 \\
(1.38 \text { to } \\
2.56)\end{array}$ & 50,176 & 59.4 & 52.7 & $\begin{array}{l}< \\
0.001\end{array}$ & \multirow{3}{*}{$\begin{array}{l}1.63 \\
(1.48 \text { to } \\
1.80) \\
1.24 \\
(1.05 \text { to } \\
1.45) \\
2.58 \\
(2.22 \text { to } \\
3.01)\end{array}$} \\
\hline $\begin{array}{l}\text { Pneumonia } \\
\text { vaccination }^{\mathrm{g}}\end{array}$ & 156 & 70.7 & 50.7 & 0.29 & $\begin{array}{l}0.51 \\
(0.08 \text { to } \\
3.34)\end{array}$ & 28,917 & 75.4 & 72.4 & 0.04 & \\
\hline HIV testing ${ }^{\mathrm{h}}$ & 6,459 & 89.0 & 58.5 & $\begin{array}{l}< \\
0.001\end{array}$ & $\begin{array}{l}4.10 \\
(2.56 \text { to } \\
6.58)\end{array}$ & 18,541 & 77.6 & 56.3 & $\begin{array}{l}< \\
0.001\end{array}$ & \\
\hline $\begin{array}{l}\text { Diabetes care } \\
\text { Hemoglobin } \\
\text { Alc checked }^{\mathrm{i}}\end{array}$ & 760 & 92.5 & 89.7 & 0.58 & $\begin{array}{l}1.70 \\
(0.39 \text { to } \\
7.47)\end{array}$ & 4267 & 92.7 & 95.0 & 0.17 & \multirow{5}{*}{$\begin{array}{l}0.63 \\
(0.34 \text { to } \\
1.18) \\
1.16 \\
(0.76 \text { to } \\
1.77) \\
1.00 \\
(0.69 \text { to } \\
1.44) \\
1.40 \\
(1.14 \text { to } \\
1.71) \\
1.16 \\
(0.93 \text { to } \\
1.45)\end{array}$} \\
\hline $\begin{array}{l}\text { Foot } \\
\text { examination }\end{array}$ & 833 & 71.1 & 66.1 & 0.53 & $\begin{array}{l}1.39 \\
(0.64 \text { to } \\
3.02)\end{array}$ & 4502 & 82.2 & 79.9 & 0.48 & \\
\hline $\begin{array}{l}\text { Eye } \\
\text { examination }\end{array}$ & 795 & 66.3 & 72.5 & 0.46 & $\begin{array}{l}0.61 \\
(0.26 \text { to } \\
1.43)\end{array}$ & 4477 & 76.7 & 77.6 & 0.79 & \\
\hline $\begin{array}{l}\text { Influenza }^{1} \\
\text { vaccination }\end{array}$ & 286 & 56.5 & 60.8 & 0.76 & $\begin{array}{l}1.06 \\
(0.29 \text { to } \\
3.81)\end{array}$ & 9689 & 64.3 & 61.4 & 0.20 & \\
\hline $\begin{array}{l}\text { Pneumonia } \\
\text { vaccination }^{\mathrm{m}}\end{array}$ & 262 & 55.2 & 43.5 & 0.44 & $\begin{array}{l}1.91 \\
(0.54 \text { to } \\
6.70)\end{array}$ & 9183 & 71.1 & 72.4 & 0.55 & \\
\hline
\end{tabular}

Years included in time periods are 2000, and 2014, 2016, and 2017. Adjusted odds ratios (aORs) were adjusted for age, sex, race, and social factors (employment, education, income, and marital status). All analyses took into account the complex survey design and weighted sampling probabilities of the data source

${ }^{a}$ Colonoscopy in the past 10 years or blood stool test in past year among participants aged 50 to 74 . Colonoscopy in the past 10 years not assessed in BRFSS 2000 data

${ }^{b}$ Mammogram in the past 2 years among women aged 50 to 74

${ }^{c}$ Pap test in the past 3 years among women aged 21 to 65

${ }^{d}$ Cholesterol checked in the past 5 years. Low-risk individuals defined as men aged $\geq 35$ and women aged $\geq 45$. High-risk individuals defined as those with a history of hypertension, hyperlipidemia, or cardiovascular disease

${ }^{e}$ Aspirin use in men aged 45 to 79 and women aged 55 to 79 , excluding those who reported having a health condition that makes taking aspirin unsafe

${ }^{f}$ Influenza vaccination in the past year among all participants

${ }^{g}$ Ever received pneumonia vaccination among participants 65 and older

${ }^{h}$ Ever tested for HIV among participants aged 18 to 65

${ }^{i}$ Hemoglobin Alc checked in the past year among participants with diabetes

${ }^{j}$ Foot examination in the past year among participants with diabetes

${ }^{k}$ Dilated eye examination in the past year among participants with diabetes

Influenza vaccination in the past year among participants with diabetes

${ }^{m}$ Ever received pneumonia vaccination among participants with diabetes 
Table 2 Difference in Recommended Preventative Health Services in Veterans with Primarily Military Coverage Compared with Non-Military Coverage over Time

\begin{tabular}{|c|c|c|c|c|}
\hline Preventative health service & $\begin{array}{l}\text { OR }(95 \% \text { CI }) \text { Interaction } \\
\text { military coverage and time } \\
\text { period }\end{array}$ & $\begin{array}{l}p \text { value for } \\
\text { interaction }\end{array}$ & $\begin{array}{l}\text { Adjusted } \mathrm{OR}^{\mathrm{a}}(95 \% \mathrm{CI}) \text { Interaction } \\
\text { military coverage and time period }\end{array}$ & $\begin{array}{l}p \text { value for } \\
\text { interaction }\end{array}$ \\
\hline \multicolumn{5}{|l|}{ Cancer screening } \\
\hline $\begin{array}{l}\text { Breast cancer } \\
\text { screening }\end{array}$ & $\begin{array}{l}2.08 \\
(0.42 \text { to } 10.41)\end{array}$ & 0.37 & $\begin{array}{l}2.21 \\
(0.42 \text { to } 11.68)\end{array}$ & 0.35 \\
\hline Cervical cancer screening ${ }^{\mathrm{c}}$ & $\begin{array}{l}0.23 \\
(0.08 \text { to } 0.66)\end{array}$ & 0.006 & $\begin{array}{l}0.22 \\
(0.09 \text { to } 0.55)\end{array}$ & 0.001 \\
\hline \multicolumn{5}{|l|}{ Cardiovascular risk reduction } \\
\hline Cholesterol checked in low-risk individuals ${ }^{\mathrm{d}}$ & $\begin{array}{l}0.42 \\
(0.12 \text { to } 1.49)\end{array}$ & 0.18 & $\begin{array}{l}0.49 \\
(0.11 \text { to } 2.25)\end{array}$ & 0.36 \\
\hline $\begin{array}{l}\text { Cholesterol checked in high-risk } \\
\text { individuals }\end{array}$ & $\begin{array}{l}0.58 \\
(0.09 \text { to } 3.96)\end{array}$ & 0.58 & $\begin{array}{l}0.36 \\
(0.04 \text { to } 2.98)\end{array}$ & 0.34 \\
\hline Aspirin use $e^{e}$ & $\begin{array}{l}1.22 \\
(0.45 \text { to } 3.31)\end{array}$ & 0.70 & $\begin{array}{l}1.89 \\
(0.63 \text { to } 5.64)\end{array}$ & 0.26 \\
\hline $\begin{array}{l}\text { Infectious disease prevention } \\
\text { Influenza vaccination }{ }^{\mathrm{f}}\end{array}$ & $\begin{array}{l}0.66 \\
(0.49 \text { to } 0.89)\end{array}$ & 0.007 & $\begin{array}{l}0.84 \\
(0.62 \text { to } 1.13)\end{array}$ & 0.25 \\
\hline Pneumonia vaccination $^{\mathrm{g}}$ & $\begin{array}{l}0.50 \\
(0.10 \text { to } 2.51)\end{array}$ & 0.40 & $\begin{array}{l}1.19 \\
(0.23 \text { to } 6.23)\end{array}$ & 0.83 \\
\hline HIV testing ${ }^{\mathrm{h}}$ & $\begin{array}{l}0.47 \\
(0.31 \text { to } 0.71)\end{array}$ & $<0.001$ & $\begin{array}{l}0.59 \\
(0.36 \text { to } 0.94)\end{array}$ & 0.03 \\
\hline \multicolumn{5}{|l|}{ Diabetes care } \\
\hline Hemoglobin A1c checked ${ }^{\mathrm{i}}$ & $\begin{array}{l}0.48 \\
(0.12 \text { to } 1.91)\end{array}$ & 0.29 & $\begin{array}{l}0.39 \\
(0.08 \text { to } 1.91)\end{array}$ & 0.25 \\
\hline Foot examination ${ }^{\mathrm{j}}$ & $\begin{array}{l}0.92 \\
(0.39 \text { to } 2.15)\end{array}$ & 0.84 & $\begin{array}{l}0.85 \\
(0.35 \text { to } 2.06)\end{array}$ & 0.71 \\
\hline Eye examination ${ }^{\mathrm{k}}$ & $\begin{array}{l}1.28 \\
(0.54 \text { to } 3.02)\end{array}$ & 0.58 & $\begin{array}{l}1.34 \\
(0.57 \text { to } 3.19)\end{array}$ & 0.50 \\
\hline Influenza vaccination ${ }^{1}$ & $\begin{array}{l}1.35 \\
(0.44 \text { to } 4.15)\end{array}$ & 0.60 & $\begin{array}{l}1.49 \\
(0.53 \text { to } 4.24)\end{array}$ & 0.45 \\
\hline Pneumonia vaccination $^{\mathrm{m}}$ & $\begin{array}{l}0.59 \\
(0.17 \text { to } 2.00)\end{array}$ & 0.39 & $\begin{array}{l}0.69 \\
(0.17 \text { to } 2.73)\end{array}$ & 0.59 \\
\hline
\end{tabular}

Interaction between military coverage and time period (2000 compared with 2014-2017). All analyses took into account the complex survey design and weighted sampling probabilities of the data source

${ }^{a}$ Adjusted odds ratios (aORs) were adjusted for age, sex, race, and social factors (employment, education, income, and marital status)

${ }^{b}$ Mammogram in the past 2 years among women aged 50 to 74

${ }^{c}$ Pap test in the past 3 years among women aged 21 to 65

${ }^{d}$ Cholesterol checked in the past 5 years. Low-risk individuals defined as men aged $\geq 35$ and women aged $\geq 45$. High-risk individuals defined as those with a history of hypertension, hyperlipidemia, or cardiovascular disease

${ }^{e}$ Aspirin use in men aged 45 to 79 and women aged 55 to 79, excluding those who reported having a health condition that makes taking aspirin unsafe ${ }^{f}$ Influenza vaccination in past year among all participants

${ }^{g}$ Ever received pneumonia vaccination among participants 65 and older

${ }^{h}$ Ever tested for HIV among participants aged 18 to 65

${ }^{i}$ Hemoglobin Alc checked in the past year among participants with diabetes

${ }^{j}$ Foot examination in the past year among participants with diabetes

${ }^{k}$ Dilated eye examination in the past year among participants with diabetes

'Influenza vaccination in the past year among participants with diabetes

${ }^{m}$ Ever received pneumonia vaccination among participants with diabetes

The difference between military coverage and non-military coverage was found to be decreasing over time for cervical cancer screening (aOR 0.22 ; 95\% CI $0.09-0.55)$ and HIV testing (aOR 0.59; 95\% CI 0.36-0.94), adjusting for patient demographics and social factors (Table 2).

\section{DISCUSSION}

In a nationally representative sample of US veterans, those who primarily used military coverage to pay for health care services had higher receipt of several preventative health services in 2000 and 2014-2017. Gaps between military and non-military coverage were found to decrease over time for cervical cancer screening and HIV testing. Limitations of our analysis include the self-reported nature of the dataset, which has been validated in other studies. ${ }^{6}$

Our results show that among veterans, while military coverage was associated with better preventative health care for several outcomes, the gap between veterans with military and non-military coverage may be narrowing. As veteran care becomes more privatized with the VA Mission Act, ongoing assessment of care delivery is critical to ensure high-quality care for this population.

Corresponding Author: Sri Lekha Tummalapalli, MD, MBA; Division of Nephrology, University of California, San Francisco, CA, USA (e-mail: lekha.tummalapall@gmail.com). 
Funding Information Dr. Tummalapalli is supported by the National Institute of Diabetes and Digestive and Kidney Diseases T32DK007219 and the Jonathan A. Showstack Career Advancement Award in Health Policy/Health Services Research at the UCSF Philip R. Lee Institute for Health Policy Studies. Dr. Keyhani is supported by VA HSR\&D PRISM QUERI Grant 1IP1HX001994.

\section{Compliance with Ethical Standards:}

Conflict of Interest: The authors declare that they do not have a conflict of interest.

\section{REFERENCES}

1. Zelaya CE, Nugent CN. Trends in Health Insurance and Type Among Military Veterans: United States, 2000-2016. Am J Public Health. 2018;108:361-7.
2. Weeks WB, West AN. Veterans Health Administration Hospitals Outperform Non-Veterans Health Administration Hospitals in Most Health Care Markets. Ann Intern Med. 2018.

3. Anhang Price R, Sloss EM, Cefalu M, Farmer CM, Hussey PS. Comparing Quality of Care in Veterans Affairs and Non-Veterans Affairs Settings. J Gen Intern Med. 2018;33:1631-8.

4. Ross JS, Keyhani S, Keenan PS, et al. Use of recommended ambulatory care services: is the Veterans Affairs quality gap narrowing? Arch Intern Med. 2008;168:950-8.

5. Hosek SD, Sorbero ME, Martsolf G, Kandrack R. Introducing ValueBased Purchasing into TRICARE Reform. Rand Health Q. 2017;6:9.

6. Caplan LS, McQueen DV, Gualters JR, Leff M, Garrett C, Calonge N. Validity of women's self-reports of cancer screening test utilization in a managed care population. Cancer Epidemiol Biomarkers Prev. 2003; 12:1182-7.

Publisher's Note Springer Nature remains neutral with regard to jurisdictional claims in published maps and institutional affiliations. 